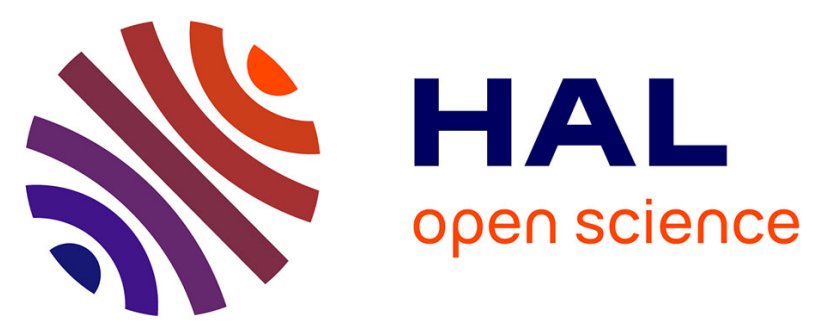

\title{
Monitoring of Venturia inaequalis harbouring the QoI resistance G143A mutation in French orchards as revealed by PCR assays
}

Séverine Fontaine, Florent Remuson, Laurence Fraissinet-Tachet, Annie Micoud, Roland Marmeisse, Delphine Melayah

\section{To cite this version:}

Séverine Fontaine, Florent Remuson, Laurence Fraissinet-Tachet, Annie Micoud, Roland Marmeisse, et al.. Monitoring of Venturia inaequalis harbouring the QoI resistance G143A mutation in French orchards as revealed by PCR assays. Pest Management Science, 2009, 65 (1), pp.74-81. 10.1002/ps.1649 . hal-00509582

\section{HAL Id: hal-00509582 \\ https://hal-anses.archives-ouvertes.fr/hal-00509582}

Submitted on 20 Aug 2010

HAL is a multi-disciplinary open access archive for the deposit and dissemination of scientific research documents, whether they are published or not. The documents may come from teaching and research institutions in France or abroad, or from public or private research centers.
L'archive ouverte pluridisciplinaire HAL, est destinée au dépôt et à la diffusion de documents scientifiques de niveau recherche, publiés ou non, émanant des établissements d'enseignement et de recherche français ou étrangers, des laboratoires publics ou privés. 


\title{
Monitoring of Venturia inaequalis harbouring the Qol resistance G143A mutation in French orchards as revealed by PCR assays
}

\author{
Séverine Fontaine, ${ }^{\text {a }}$ Florent Remuson, ${ }^{\text {a }}$ Laurence Fraissinet-Tachet, ${ }^{\text {b }}$ \\ Annie Micoud, ${ }^{a}$ Roland Marmeisse ${ }^{b}$ and Delphine Melayah ${ }^{\text {b* }}$
}

\begin{abstract}
BACKGROUND: Genetic resistance to Qol fungicides may account for recent failures to control Venturia inaequalis (Cooke) Winter in French orchards. Two PCR-based assays were developed to detect the G143A point mutation in the fungal mitochondrial cytochrome b gene. The mutation is known to confer a high level of resistance to Qol fungicides. Occurrence of the G143A mutation in French field isolates collected from 2004 to 2007 was monitored.

RESULTS: The Qol-resistant cytochrome b allele was specifically detected either following the cleavage of the amplified marker by a restriction endonuclease (CAPS assay) or its amplification using an allele-specific PCR primer. Using either method, the G143A mutation was found in $42 \%$ of the 291 field samples originating from French orchards in which apple scab proved difficult to be controlled. Monitoring of the G143A mutation in orchards located in 15 French administrative regions indicated that the mutation was detected at least once in nine of the regions, and its presence ranged from $33 \%$ to $64 \%$ of the orchards analysed in 2004 and in 2007 respectively.
\end{abstract}

CONCLUSION: The PCR-based methods developed in this study efficiently reveal the presence of the G143A mutation in French $V$. inaequalis field populations.

(C) 2008 Society of Chemical Industry

Supporting information may be found in the online version of this article.

Keywords: Venturia inaequalis; apple scab; Qol; fungicide resistance; allele-specific PCR; molecular diagnostics

\section{INTRODUCTION}

Apple scab, caused by the fungus Venturia inaequalis (Cooke) Winter, is characterised by brown to olive-coloured spots on apple tree leaves and fruits. This major disease in apple tree orchards is mainly controlled through fungicide treatments. Quinone outside inhibiting (Qol) fungicides are one of the latest families of chemicals that play an important role in plant protection against many phytopathogenic fungi including $V$. inaequalis. These molecules specifically inhibit cell respiration by binding at the ubiquinol oxidation centre (Qo site) of the mitochondrial cytochrome bc1 complex. ${ }^{1,2}$

Resistance to Qol fungicides has been detected in several fungal pathogens such as Blumeria graminis Speer ${ }^{3}$ and Mycosphaerella fijiensis Morelet ${ }^{4}$ or Oomycetes such as Pseudoperonospora cubensis (Burk. \& Curt.) Rostosev. ${ }^{5-7}$ Qol resistance in V. inaequalis was first reported in 1997 in European field and experimental trials. ${ }^{8}$ In France, the commercial Qol fungicides used to control $V$. inaequalis correspond to strobilurins. Although strobilurins have been successfully used on apple trees to control scab since 1998, the first cases of Qol resistance that occurred in French commercial apple tree orchards were reported in 2002 (unpublished results from the Service Régional Rhône-Alpes de la Protection des Végétaux, France). Several mechanisms leading to Qol resistance have been reported in $V$. inaequalis. One known mode of resistance is the metabolisation of kresoxim-methyl, a commercial strobilurin molecule, by esterases and cytochrome P450 monooxygenases. ${ }^{9}$ Under laboratory conditions, induction of the alternative respiration pathway has also been observed during conidia germination. ${ }^{10}$ This latter phenomenon could possibly occur in apple tree orchards and contribute to resistance in the field. ${ }^{8}$ Finally, the commonly found target-site mutation referred to as the G143A mutation, which accounts for a high level of resistance to Qol in many plant pathogens, has also been identified in Qol-resistant V. inaequalis isolates. This point mutation occurs in the mitochondrial cytochrome b (Cyt b) gene and results in a change of glycine to alanine at position 143 of the protein. ${ }^{11}$ However, Steinfeld et al. ${ }^{12}$ obtained an isolate of $V$. inaequalis that

\footnotetext{
Correspondence to: Delphine Melayah, Université de Lyon, Université Lyon 1 Ecologie Microbienne, UMR CNRS 5557, USC INRA 1193, Bâtiment André Lwoff, 43 Boulevard du 11 Novembre 1918, F-69622 Villeurbanne Cedex, France. E-mail:delphine.melayah@univ-lyon1.fr

a DRAF-SRPV Rhône Alpes, Cité Administrative de la Part Dieu, Bât B, 165 rue Garibaldi, Lyon, F69003, France

b Université de Lyon, Université Lyon 1, Ecologie Microbienne, UMR CNRS 5557, USC INRA 1193, Bâtiment André Lwoff, 43 Boulevard du 11 Novembre 1918, F-69622 Villeurbanne Cedex, France
} 
presented a high level of resistance to Qol without the G143A mutation from an experimental orchard in Switzerland. As the alternative oxidase pathway was not found to be overexpressed in this isolate, additional mutations in genes encoding components of the cytochrome bc1 complex were suspected.

Monitoring of Qol resistance from field-collected infected material (leaves, apples) is of practical importance to evaluate the efficiency of these molecules and to reorient fungicide treatments in the corresponding orchards. Currently, detection of $V$. inaequalis Qol-resistant isolates relies on in vitro test systems based on spore germination on fungicide-amended media. As viability of $V$. inaequalis conidia recovered from commercial orchards treated with pesticides is usually low, alternative monitoring methods are needed. PCR-based detection is a valuable tool when the fungicideresistant phenotype is clearly associated with a known point mutation. This is the case for the single nucleotide polymorphism that characterises the G143A mutation in the Cyt $b$ gene of several fungal Qol-resistant pathogens including $V$. inaequalis.

The objectives of this study were to develop a rapid molecular test to detect the G143A mutation in field-collected apple scab lesions and to use this method to monitor this point mutation in apple tree orchards in France. Two methods based on the amplification of a portion of the Cyt $b$ gene were developed. The first one requires the digestion of PCR products with a restriction enzyme that specifically cleaves the amplified fragment at the site of the mutation. The second one is an allele-specific PCR detection using an oligonucleotide primer that specifically binds to the mutant sequence.

\section{MATERIALS AND METHODS}

\subsection{Fungal isolates}

Two strains of $V$. inaequalis were isolated from infected apple tree leaves and maintained in pure culture on potato dextrose agar medium (Table 1). The Qol-sensitive single-spore isolate SFR2, collected in July 2002 originated from an orchard that had never been treated with fungicides. Single-spore isolate 160 , collected in June 2003 from a commercial orchard in south France, displayed a high resistance factor $(\mathrm{RF}=283$ ) towards kresoxim-methyl (see Section 2.4). In addition to $V$. inaequalis isolates, strains of Botrytis cinerea Pers., Rhizopus sp. and Penicillium sp. were used to test for the specificity of the PCR primers (Table 1 ).

A total of 317 field samples were collected from 2004 to 2007, and 291 were analysed (see supporting information in Table S1). They originated from commercial and experimental French orchards where strobilurin treatments were suspected to be ineffective to control the pathogen. Infected apple leaves collected from orchards that had never been treated with any fungicides were used as control Qol-sensitive field samples.

For each orchard, V. inaequalis spores were collected from 30-50 lesion-bearing leaves or fruits with a brush. Spore suspensions were adjusted in distilled water to $1 \times 10^{5}$ conidia $\mathrm{mL}^{-1}$. For each orchard, 30 lesions on leaves (ca $0.6 \times 0.6 \mathrm{~cm}$ ) or fruits (ca $100 \mathrm{mg}$ ) were collected ( 1 lesion per leaf or fruit), pooled and stored at $-20^{\circ} \mathrm{C}$ until DNA extraction. In addition, individual leaf lesions were frozen separately. The latter samples were used as starting material to evaluate the detection thresholds of both PCR methods.

\subsection{DNA extraction}

Frozen mycelia as well as mixed and unique lesion samples were ground in liquid nitrogen using a mortar and pestle. Fungal DNA or
Table 1. Geographic origin and sampling year of the fungal isolates used in this study

\begin{tabular}{|c|c|c|c|}
\hline Isolates & $\begin{array}{l}\text { Sampling } \\
\text { year }\end{array}$ & $\begin{array}{l}\text { French administrative } \\
\text { region (locality) }\end{array}$ & $\begin{array}{c}\mathrm{EC}_{50}{ }^{\mathrm{a}} \\
\left(\mathrm{mg} \mathrm{L}^{-1}\right)\end{array}$ \\
\hline \multicolumn{4}{|c|}{ Venturia inaequalis } \\
\hline SFR2 & 2002 & $\begin{array}{l}\text { Rhône-Alpes (Saint } \\
\text { Marcel d'Urfé) }\end{array}$ & 0.06 \\
\hline 160 & 2003 & $\begin{array}{l}\text { Midi-Pyrénées } \\
\text { (Montauban) }\end{array}$ & 8.5 \\
\hline Botrytis cinerea & 2003 & $\begin{array}{l}\text { Rhône-Alpes (Saint } \\
\text { Genis Laval) }\end{array}$ & $n d^{b}$ \\
\hline Rhizopus sp. & 2003 & $\begin{array}{l}\text { Rhône-Alpes (Saint } \\
\text { Didier sous Riverie) }\end{array}$ & $n d^{b}$ \\
\hline Penicillium sp. & 2003 & $\begin{array}{l}\text { Rhône-Alpes (Saint } \\
\text { Didier sous Riverie) }\end{array}$ & $n d^{b}$ \\
\hline \multicolumn{4}{|c|}{$\begin{array}{l}{ }^{a} E C_{50} \text { refers to the concentration of kresoxim-methyl that leads to a } \\
50 \% \text { inhibition of the mycelia growth rate. } \\
{ }^{b} \mathrm{nd}=\text { not determined. }\end{array}$} \\
\hline
\end{tabular}

DNA from a plant-fungus mixture was extracted and purified using Nucleospin Plant DNA extraction kit (Macherey Nagel) according to the manufacturer's recommendations. DNA was resuspended in $100 \mu \mathrm{L}$ of elution buffer and quantified using a NanoDrop ${ }^{\circledR}$ ND-1000 spectrophotometer.

\subsection{PCR-based detection}

\subsubsection{Cleaved amplified polymorphic sequence (CAPS) assay}

The PCR primers PS1 and PR1 (Table 2) were designed using the published sequence of the $V$. inaequalis Cyt $b$ gene (GenBank accession number AF004559). ${ }^{13}$ They hybridise in exons 3 and 4 of the gene, respectively, and amplify a 488 bp fragment containing the region of interest, i.e. codon 143 site of the G143A mutation. This point mutation changes the sequence $5^{\prime}-\mathrm{GGTGC}-3^{\prime}$ into $5^{\prime}$-GCTGC-3', which is specifically recognised by the restriction endonuclease Fnu4HI.

PCR amplifications were performed in a $25 \mu \mathrm{L}$ volume containing $1 \mu \mathrm{L}$ of DNA (1-10 ng), $0.5 \mu \mathrm{M}$ of each primer, $200 \mu \mathrm{M}$ of each dNTP, $0.5 \mathrm{~mm}$ magnesium chloride and $2 \mathrm{U}$ of TaqDNA polymerase in the appropriate buffer (Invitrogen). An initial denaturation step at $94^{\circ} \mathrm{C}$ for 3 min was followed by 35 cycles that each included a denaturation at $94^{\circ} \mathrm{C}$ for $30 \mathrm{~s}$, a primer annealing step at $55^{\circ} \mathrm{C}$ for $45 \mathrm{~s}$ and a polymerisation step at $72^{\circ} \mathrm{C}$ for $50 \mathrm{~s}$. Amplifications were terminated by a 5 min final extension at $72{ }^{\circ} \mathrm{C}$. PCR products from the sensitive (SFR2) and resistant (160) isolates were directly sequenced using the BigDye3.1 Terminator sequencing kit (Applied Biosystems) and analysed on an ABI3730XL capillary sequencer (Applied Biosystems) at Genoscreen Services (Lille, France). A quantity of $10 \mu \mathrm{L}$ of the PCR products was digested overnight by $1.5 \mathrm{U}$ of Fnu4HI (New England Biolabs) at $37^{\circ} \mathrm{C}$. Restriction fragments were separated on $2.5 \%$ agarose gels in $0.5 \times$ TBE and stained with ethidium bromide. Gels were visualised using a UV transilluminator and photographed using the Gel Doc 2000 apparatus (BioRad).

\subsubsection{Allele-specific PCR (AS-PCR)}

Allele-specific PCR primers that would preferentially bind to the mutant sequence were designed. The backbone sequence of these primers corresponds to primer G143AMM0 for which the 3' $\mathrm{G}$ nucleotide is complementary to the $C$ residue specific to the 
Table 2. Primers used in this study. For the allele-specific primers G143AMM0 to G143AMM4, the introduced mismatch bases relative to the Venturia inaequalis Cyt $b$ wild-type sequence are underlined

\begin{tabular}{|c|c|c|c|}
\hline Name & Orientation & Sequence $\left(5^{\prime} \rightarrow 3^{\prime}\right)$ & Nucleotide position $^{a}$ \\
\hline PS1 & Forward & GTTACAGCCTTCCTGGGTTAT & $5025-5045$ \\
\hline PR1 & Reverse & AGGCCTCCCCACAGAAATTCG & $5513-5495$ \\
\hline G143AMM0 & Reverse & GGTTTGTGATGACAGTTGCAG & $5457-5437$ \\
\hline G143AMM1 & Reverse & GGTTTGTGATGACAGTTGCTG & $5457-5437$ \\
\hline G143AMM2 & Reverse & 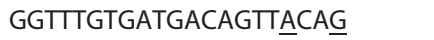 & $5457-5437$ \\
\hline G143AMM3 & Reverse & GGTTTGTGATGACAGTTGTAG & $5457-5437$ \\
\hline G143AMM4 & Reverse & GGTTTGTGATGACAGTTGGAG & $5457-5437$ \\
\hline PS-exon7 & Forward & GGTGTTATAGCTATGTTTGCAGCTA & $10394-10418$ \\
\hline PR-exon7 & Reverse & CAAGAGGTACAATTCACAAAGTGAG & $10631-10605$ \\
\hline
\end{tabular}

mutant allele (Table 2). Enhanced allelic discrimination was tested by introducing an additional mismatch in the $3^{\prime}$ subterminal region of the primer, thus creating primers G143AMM1, G143AMM2, G143AMM3 and G143AMM4 (Table 2). These allele-specific primers were used in combination with primer PS1 and tested to amplify a 433 bp DNA fragment.

All AS-PCR reactions included, as an amplification control, a second set of primers, namely PS-exon7 and PR-exon7 (Table 2). This primer pair allows, from any $V$. inaequalis $C y t b$ alleles, the amplification of a $238 \mathrm{bp}$ sequence located some $5 \mathrm{~kb}$ downstream of the G143 mutation. PCR amplifications were performed in a $25 \mu \mathrm{L}$ volume containing $0.2 \mu \mathrm{M}$ of allele-specific primers and $0.1 \mu \mathrm{M}$ of control primers (PS-exon7 and PR-exon7). Other AS-PCR components included $1 \mu \mathrm{L}$ of DNA $(1-10 \mathrm{ng}), 400 \mu \mathrm{M}$ of each dNTP, $0.5 \mathrm{~mm}$ of magnesium chloride and $2 \mathrm{U}$ of Taq-DNA polymerase in the appropriate buffer (Invitrogen). An initial denaturation at $94{ }^{\circ} \mathrm{C}$ for $3 \mathrm{~min}$ was followed by 30 cycles that each included denaturation at $94^{\circ} \mathrm{C}$ for $30 \mathrm{~s}$, a primer annealing step at $60^{\circ} \mathrm{C}$ for $45 \mathrm{~s}$, and extension at $72^{\circ} \mathrm{C}$ for $50 \mathrm{~s}$. Amplifications were followed by a final extension of $3 \mathrm{~min}$ at $72^{\circ} \mathrm{C}$. PCR products were separated on $1 \%$ agarose gels in $0.5 \times$ TBE and stained with ethidium bromide.

\subsubsection{Detection thresholds of PCR assays}

Total DNA extracted from leaves colonised by a Qol-sensitive fungal isolate was mixed at different ratios with DNA extracted from leaves contaminated by a G143A positive isolate. CAPS assay and AS-PCR were carried out as described above using $3 \mathrm{ng}$ of mixed DNA samples as template.

\subsection{Spore germination assay}

The Qol fungicide used in bioassays was kresoxim-methyl (BASF). It was of technical-grade quality ( $97.8 \%$ purity). Stock solutions of kresoxim-methyl were prepared in ethanol, and varying volumes of these were added to water agar to achieve final concentrations that ranged from $1 \times 10^{-3}$ to $3 \times 10^{2} \mathrm{mg} \mathrm{Al} \mathrm{L}^{-1}$ of medium. Randomly selected spore suspensions were also spread on kresoxim-methylcontaining medium amended with salicylhydroxamic acid (SHAM) at a final concentration of $30 \mathrm{mg} \mathrm{L}^{-1}$.

A freshly prepared conidial suspension was spread on each of the different media at a density of about 230 conidia per $19.6 \mathrm{~cm}^{2}$ Petri dish. Plates were incubated in the dark, at $20-22^{\circ} \mathrm{C}$, for $48 \mathrm{~h}$. A total of 100 conidia were then scored as either germinated or not. For each fungicide concentration, the germination rate was calculated as the percentage germination on the fungicidesupplemented medium divided by the mean of percentage germination on the control, fungicide-free, medium. The $50 \%$ effective concentration $\left(E_{50}\right)$ was calculated using the regression curves obtained by graphically plotting the germination rates against the log-transformed value of the fungicide concentrations. The resistance factor (RF) corresponded to the $\mathrm{EC}_{50}$ value of the studied orchard divided by the $\mathrm{EC}_{50}$ value obtained from control orchards that had never been treated with strobilurins. For each analysis, the minimal inhibitory concentration (MIC) was determined.

\section{RESULTS}

\subsection{PCR-based detection of the G143A mutation in Venturia inaequalis}

3.1.1 Cleaved Amplified polymorphic sequence (CAPS) assay

The preliminary set of this experimental work consisted of controlling the primer specificity towards $V$. inaequalis. Primer pair PS1-PR1 amplified a $488 \mathrm{bp}$ fragment from DNA samples extracted from pure cultures of both Qol-sensitive (isolate SFR2) and resistant (isolate 160) $\mathrm{V}$. inaequalis mycelia, as well as from DNA extracted from $V$. inaequalis-infected apple leaves and fruits collected in orchards. No amplification was obtained using DNA from non-infected apple tree leaves or other fungi such as Botrytis cinerea, Penicillium sp. and Rhizopus sp. (data not shown).

Sequences of the PCR products from the sensitive and resistant isolates were identical to the published sequence of $V$. inaequalis $C y t b$ gene, except for a guanine to cytosine transversion in the sequence from the isolate 160 responsible for the typical G143A mutation conferring Qol resistance (Fig. 1). This mutation created an Fnu4HI (5'-GCTGC-3') restriction site in the mutant sequence. Upon digestion with this endonuclease, two DNA fragments of 412 and $76 \mathrm{bp}$ were obtained with the PCR fragment from the resistant isolate 160 , whereas, as expected, the PCR product from the sensitive isolate SFR2 was not cleaved (Fig. 2), allowing CAPS analysis on composite samples. As a control for population analysis, DNA amplified from lesions collected in several control orchards that had never been treated with strobilurins could not be digested by Fnu4HI. On the other hand, DNA amplified from numerous samples collected in orchards in which strobilurin treatments failed to control apple scab were frequently partially digested by Fnu4HI (Fig. 2). Partial digestions probably resulted from the coamplification of sensitive and resistant Cyt $b$ alleles, as the field- 


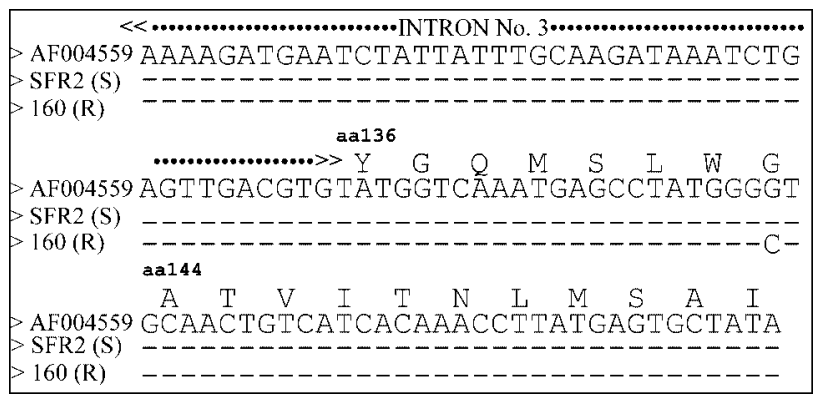

Figure 1. Partial alignment of the cytochrome $b$ sequences from the Qolsensitive (SFR2) and resistant (160) Venturia inaequalis isolates to the GeneBank AF004559 sequence. Note the $\mathrm{G}$ to $\mathrm{C}$ transversion at nucleotide position 5437 of the Cyt $b$ gene, leading to the amino acid change glycine to alanine responsible for Qol resistance.

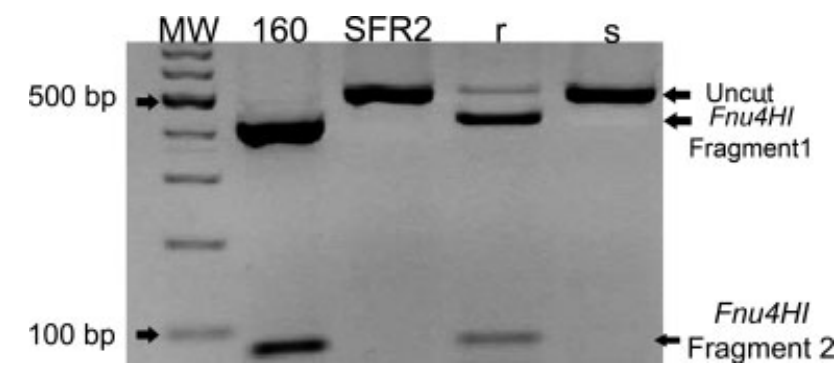

Figure 2. Fnu4HI digestion of the $488 \mathrm{bp} \mathrm{PCR} \mathrm{fragment} \mathrm{of} \mathrm{the} \mathrm{cytochrome}$ b gene generated by primer pair PS1-PR1 using DNA extracted from Qol-resistant Venturia inaequalis isolate 160 (lane 2), Qol-sensitive isolate SFR2 (lane 3) and apple scab lesions collected in an orchard where resistant isolates predominated ( $r$; lane 4 ) or were absent ( $s$; lane 5). MW, 1 kb DNA ladder (Fermentas).

collected samples are composite samples made up of 30 different apple scab lesions.

The sensitivity of the CAPS method was tested by establishing different ratios of DNA extracted from leaves infected with a Qolresistant $(\mathrm{R})$ isolate with DNA extracted from leaves infected with a Qol-sensitive (S) isolate. The Qol-resistant allele could not be detected after Fnu4HI digestion for R:S ratios equal to or below $1: 9$ (w:w) (Fig. 3).

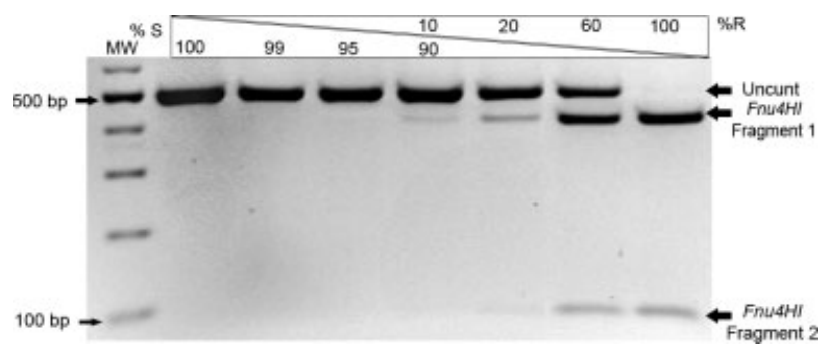

Figure 3. Sensitivity of the CAPS method. DNA extracted from individual lesions caused by Qol-resistant (R) and Qol-sensitive (S) isolates were mixed at different ratios (from 1:99 to $40: 60, \mathrm{w}: \mathrm{w}$ ) before amplification of a Cyt $b$ 488 bp DNA fragment which was digested with Fnu4HI. The $100 \%$ sensitive and $100 \%$ resistant corresponded to DNA extracted from mycelium of the Qol-sensitive isolate SFR2 and the Qol-resistant isolate 160, respectively. MW, 1 kb DNA ladder (Fermentas).

\subsubsection{Allele-specific PCR (AS-PCR)}

In order to improve the sensitivity of the PCR detection method, the authors developed an AS-PCR method. For this purpose, primer PS1, which should hybridise to any $V$. inaequalis $C y t b$ allele, was combined with a second primer designed to bind specifically to the sequence of the mutant allele conferring Qol resistance. The first AS primer designed, G143AMM0 (Table 2), differed from the wild-type sequence by having a $\mathrm{G}$ at its $3^{\prime}$ end, which corresponds to the G143A mutation. Using the primer pair PS1-G143AMM0, both wild-type and mutant alleles were equally amplified at either annealing temperature tested (data not shown). Therefore, four additional AS primers that differed from G143AMM0 by a second mismatch in position $-1,-2$ or -3 relative to the $3^{\prime}$ end of the primer were designed (Table 2). In combination with primer PS1, these four primers amplified a $433 \mathrm{bp}$ fragment from both sensitive and resistant isolates at an annealing temperature of $55^{\circ} \mathrm{C}$. Allelic discrimination, i.e. specific amplification of the Qol-resistant allele, was achieved using any of the four primer pairs at the annealing temperature of $60^{\circ} \mathrm{C}$ (Fig. 4). Primer G143AMM1 was then chosen as the AS primer for all subsequent experiments. To make sure that the absence of amplification of a $433 \mathrm{bp}$ fragment did not result from PCR inhibition, all AS-PCR reactions included a second primer pair (PS-exon7 and PR-exon7), which allowed the amplification of a 238 bp fragment from all Cyt $b$ alleles (Fig. 4).

The sensitivity of the AS-PCR protocol was evaluated by amplifying Cyt $b$ mutant allele DNA molecules when mixed at different ratios with wild-type allele molecules. The mutant allele was amplified at the lowest ratio tested, 1\% of DNA extracted from leaves infected with a Qol-resistant isolate to $99 \%$ of DNA extracted from leaves infected with a Qol-sensitive isolate (Fig. 5), thus showing a higher sensitivity of the AS-PCR detection method compared with CAPS analysis.

\subsection{Spore germination assay versus molecular detection methods}

Among the 317 samples collected from orchards from 2004 to 2007, only 284 samples were analysed for Qol resistance by both the bioassay and the PCR approaches. The 33 remaining samples were only tested by PCR approaches. Here, $74 \%$ of spore germination assays could not be interpreted owing to an excessively low quantity of spores collected from the leaves or

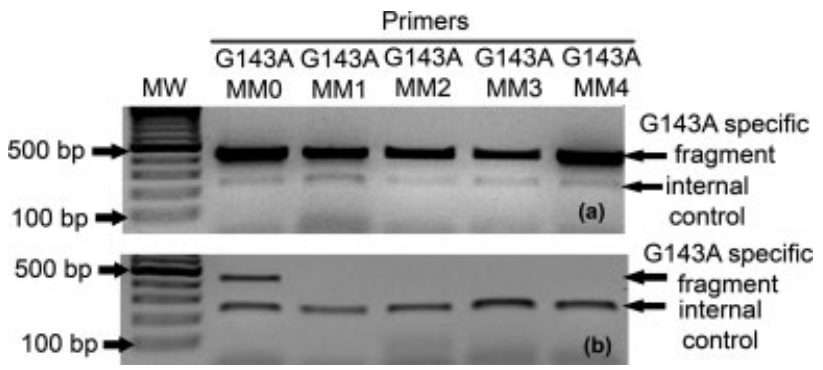

Figure 4. Allele-specific PCR amplification of the G143A Cyt $b$ allele. DNA extracted from Venturia inaequalis Qol-resistant (a) and sensitive (b) isolates were used as templates for the PCR amplifications which used primer PS1 in combination with one of the five allele-specific primers G143AMM0 to G143AMM4 that specifically bind to the mutant cytochrome b sequence. As a positive amplification control, primers PS-exon7 and PRexon7, which amplify a 238 bp fragment, were included in all PCR reactions. Primer G143AMM0, which differs from the wild-type sequence by one nucleotide at its $3^{\prime}$ end, was not specific at an annealing temperature of $60{ }^{\circ} \mathrm{C}$. MW, 1 kb DNA ladder (Fermentas). 


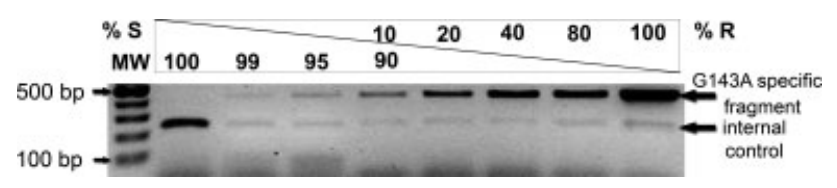

Figure 5. Sensitivity of the allele-specific PCR method. DNA extracted from Qol-resistant ( $\mathrm{R}$ ) and Qol-sensitive $(\mathrm{S})$ isolates were mixed at different ratios (from $1: 99$ to $80: 20, w: w$ ) before coamplification at $60^{\circ} \mathrm{C}$ by primer pair PS1-G143AMM1 of a G143A-specific 433 bp fragment and by primer pair PS-exon7 and PR-exon7 of a control 238 bp fragment. The $100 \%$ sensitive and $100 \%$ resistant corresponded to DNA extracted from mycelium of the Qol-sensitive isolate SFR2 and the Qol-resistant isolate 160, respectively. MW, 1 kb DNA ladder (Fermentas).

to a very low germination rate on Qol-free medium, although an unusually low threshold value of $10 \%$ was used. In contrast, only in $8 \%$ of these samples did PCR amplification of the Cyt $b$ fragment fail. This could be ascribed to degradation of the DNA extracted from excessively old lesion tissues or leaf samples not well preserved between their collection and delivery in the laboratory.

The Qol-sensitive isolate SFR2 showed 50\% mycelia growth inhibition when using $0.06 \mathrm{mg} \mathrm{L}^{-1}$ of kresoxim-methyl (Table 1). Comparatively, Qol-resistant isolate 160 exhibited an $\mathrm{EC}_{50}$ for mycelium of $8.5 \mathrm{mg} \mathrm{L}^{-1}$ of Qol fungicide. The present data are consistent with the baseline sensitivity $\left(0.09 \mathrm{mg} \mathrm{L}^{-1}\right)$ and the mean $\mathrm{EC}_{50}$ value $\left(6.09 \mathrm{mg} \mathrm{L}^{-1}\right)$ found in $V$. inaequalis populations exposed to kresoxim-methyl in Quebec orchards. ${ }^{14}$ Using kresoxim-methyl, the $\mathrm{EC}_{50}$ for spores collected in French orchards that had never been treated with strobilurin varied between 0.001 and $0.006 \mathrm{mg} \mathrm{L}^{-1}$ (Table 3). These $\mathrm{EC}_{50}$ values are in accordance with literature data found for sensitive isolates (0.0006-0.007 $\left.\mathrm{mg} \mathrm{L}^{-1}\right){ }^{8,12}$ As illustrated in Fig. 6, spores collected in 46 of the 73 analysed orchards had $\mathrm{EC}_{50}$ values that were at least 10 times higher (up to more than $10^{4}$ times) than the values recorded for sensitive fungal isolates. For the resistant groups of orchards that were considered from in vitro germination tests as being infected by Qol-resistant isolates, molecular analyses made it possible to detect the presence of the G143A mutation in 35 (76\%) of them. For the remaining 11 resistant orchards, the G143A mutation could not be detected by a PCR approach, in spite of the fact that their $\mathrm{EC}_{50}$ and MIC values were respectively $10-10000$ and
5-10000 times higher than values recorded for sensitive fungal isolates (mean $\mathrm{EC}_{50}=0.004 \mathrm{mg} \mathrm{L}^{-1}$; highest $\mathrm{MIC}=0.03 \mathrm{mg} \mathrm{L}^{-1}$ ).

For the second group of the 27 remaining orchards, for which the $\mathrm{EC}_{50}$ values of the $V$. inaequalis spores ranged from 0.002 to $0.04 \mathrm{mg} \mathrm{L}^{-1}$ of kresoxim-methyl, the G143A mutation could be detected only in four of them.

\subsection{Occurrence of the G143A mutation in French orchards} from 2004 to 2007

From 2004 to 2007, infected leaves were sampled in 281 different commercial orchards in which fungicide treatments failed to limit the spread of apple scab, and 255 were successfully analysed by either PCR-based method. A total of 29 orchards were analysed over 2 years ( 22 orchards) or 3 years ( 7 orchards). In total, this represented 291 sample analyses. In 2004 and 2005 the samples were exclusively analysed using the CAPS method. In 2006, 67 samples were analysed by the CAPS method and 20 using AS-PCR (Table 4). Among the 67 initially analysed by CAPS, 21 were found to be positive and 46 to be negative for the mutation. Among these latter, 33 of them were reanalysed by AS-PCR, and five of them (15\%) turned out to be positive for the mutation using this latter method. In 2007, all samples were analysed by AS-PCR.

Table 4. Prevalence of the Venturia inaequalis Cyt $b$ G143A mutation in orchards sampled from 2004 to 2007, as revealed by either the CAPS method or allele-specific PCR (AS-PCR)

\begin{tabular}{lccccc} 
& \multicolumn{2}{c}{ CAPS } & & \multicolumn{2}{c}{ AS-PCR } \\
\cline { 2 - 3 } \cline { 5 - 6 } $\begin{array}{l}\text { Sampling } \\
\text { year }\end{array}$ & $\begin{array}{c}\text { No. of } \\
\text { orchards }\end{array}$ & $\begin{array}{c}\text { G143A mutation } \\
\text { present }\end{array}$ & $\begin{array}{c}\text { No. of } \\
\text { orchards }\end{array}$ & $\begin{array}{c}\text { G143A mutation } \\
\text { present }\end{array}$ \\
\hline 2004 & 46 & 15 & & - & - \\
2005 & 125 & 43 & & - & - \\
2006 & 67 & 21 & & $53^{\mathrm{a}}$ & $21^{\mathrm{b}}$ \\
2007 & - & - & & 33 & 21 \\
$2004-2007$ & 238 & 79 & & 86 & 42 \\
\end{tabular}

a Twenty unique samples +33 that were found to be negative in the CAPS assay.

${ }^{\mathrm{b}}$ Among which 5 were found to be negative by the CAPS method.

Table 3. Sensitivity to kresoxim-methyl of Venturia inaequalis spores collected in control orchards that had never been treated with strobilurins

\begin{tabular}{|c|c|c|c|c|c|}
\hline Orchard & Sampling year & Geographic origin ${ }^{a}$ & Germination $^{\mathrm{b}}(\%)$ & $\mathrm{EC}_{50}^{\mathrm{c}}\left(\mathrm{mg} \mathrm{L}^{-1}\right)$ & $\operatorname{MIC}^{d}\left(\mathrm{mg} \mathrm{L}^{-1}\right)$ \\
\hline FR B & 2005 & Saint Marcel d'Urfé & 10 & 0.006 & 0.03 \\
\hline FR B & 2007 & Saint Marcel d'Urfé & 20 & 0.005 & 0.03 \\
\hline FR M & 2005 & Saint Marcel d'Urfé & 12 & 0.002 & 0.01 \\
\hline FR M & 2006 & Saint Marcel d'Urfé & 13 & 0.003 & 0.01 \\
\hline FR M & 2007 & Saint Marcel d'Urfé & 14 & 0.006 & 0.03 \\
\hline FR V & 2005 & Saint Marcel d'Urfé & 10 & 0.001 & 0.01 \\
\hline FR V & 2007 & Saint Marcel d'Urfé & 15 & 0.005 & 0.03 \\
\hline VB & 2004 & Givors & 28 & 0.004 & 0.03 \\
\hline CB & 2004 & Saint Jean le Vieux & 20 & 0.005 & 0.01 \\
\hline \multicolumn{3}{|l|}{ Mean $( \pm S D)$} & $15.7( \pm 5.5)$ & $0.004( \pm 0.002)$ & $0.02( \pm 0.01)$ \\
\hline $\begin{array}{l}\text { a Localities ar } \\
\mathrm{b} \text { Percentage } \\
{ }^{c} \mathrm{EC}_{50} \text { refers } \mathrm{t} \\
\mathrm{d} \text { MIC is the } \mathrm{m}\end{array}$ & $\begin{array}{l}\mathrm{d} \text { in the French } \\
\text { on refers to the } \\
\text { icide concentra } \\
\text { centration of fu }\end{array}$ & $\begin{array}{l}\text { ative region Rhône } \\
\text { ained on fungicide- } \\
\text { eads to a } 50 \% \text { inhib } \\
\text { hat entirely inhibits }\end{array}$ & $\begin{array}{l}\text { n. } \\
\text { germination rate. } \\
\text { ination. }\end{array}$ & & \\
\hline
\end{tabular}




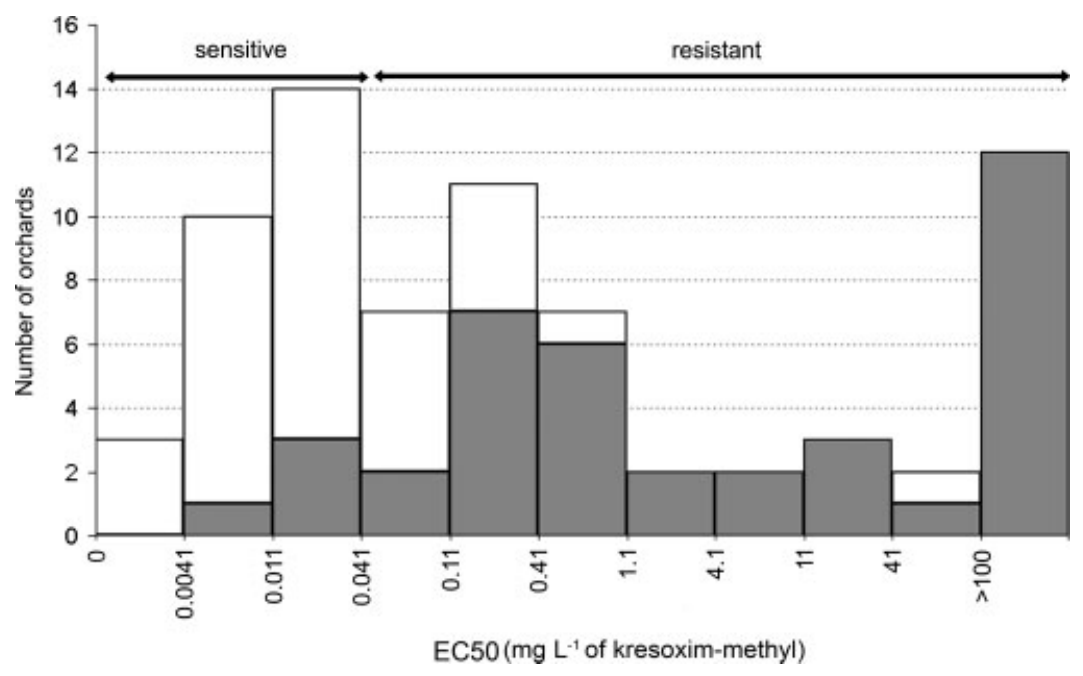

Figure 6. Distribution of the studied apple tree orchards according to the sensitivity of their Venturia inaequalis populations to kresoxim-methyl, as determined by spore germination assays. An arbitrary threshold value of $0.04 \mathrm{mg} \mathrm{L}^{-1}$ of fungicide (tenfold EC 50 and twofold MIC of sensitive isolates) is usually used to separate the 'sensitive' from the 'resistant' fungal populations. Grey bars represent the number of orchards in which the G143A mutation was detected and white bars the number of orchards in which it could not be detected using either PCR-based method.

The G143A mutation was detected in 15 orchards (32\%) in 2004, 43 (34\%) in 2005, 42 (48\%) in 2006 and 21 (64\%) in 2007. Four out of the 238 samples analysed by the CAPS method revealed that the amplified 488 bp fragment was entirely digested by Fnu4HI, thus suggesting that, in these four situations, the G143A mutation predominated among the different $V$. inaequalis isolates present in each of these four orchards. For the 29 orchards analysed over 2 or 3 years, the mutation was detected in the first year of monitoring for 12 of them. Except for one orchard, the mutation continued to be detected over this time period, in spite of an alleged cessation of strobilurin treatments in these orchards.

The present analyses clearly indicated the repeated occurrence of the G143A mutation in multiple apple-producing regions in France all through the sampling years (Fig. 7). Indeed, in 2004 the mutation was recorded in three $(33 \%)$ regions out of the nine from which samples were analysed: Midi-Pyrénées, Rhône-Alpes and Provence-Alpes-Côte d'Azur. In 2005, five (42\%) regions out of 12 contained the mutation, six (54\%) out of 11 in 2006 and all seven in 2007. In the two administrative regions where the G143A mutation had prevailed since 2004 (the Midi-Pyrénées and RhôneAlpes regions), a global increase in the percentages of orchards with the G143A mutation was noticed, ranging from $73 \%$ in 2004 to $86 \%$ in 2006 in Midi-Pyrénées and from $67 \%$ in 2004 to $84 \%$ in 2006 in Rhône-Alpes (Fig. 7).

\section{DISCUSSION}

As one of the major pathogens of apple trees, it is necessary to monitor the occurrence, origin and distribution of fungicide resistance in $V$. inaequalis in order to optimise the use of pesticides in apple tree orchards. Single-target-site Qol fungicides have become popular to control apple scab. Recent reports of Qol resistance in the field have suggested that mutations conferring this phenotype could have been selected several times independently and/or were disseminating among pathogen populations. $^{15-17}$

As shown in this study, spore germination assays on fungicidesupplemented media, although effective to estimate resistance levels, fail to give interpretable results in many cases owing to very low spore viability in field-collected samples. Indeed, field samples have often been exposed to additional fungicides other than Qol molecules, which, in addition to delays between collection time in the field and processing in the laboratory, may affect spore viability. Nevertheless, spore germination assays demonstrate that, in about $25 \%$ of the samples that were processed, the failure properly to control apple scab could not be attributed to Qol resistance, as both the $\mathrm{EC}_{50}$ and the RF values for these samples were similar to the values recorded for samples collected in control orchards contaminated by Qol-sensitive V. inaequalis isolates.

Detection of the G143A mutation by the CAPS method and/or AS-PCR has already been reported for several plant pathogens such as Magnaporthe grisea (Hebert) Barr, ${ }^{18}$ Erysiphe graminis DC ${ }^{19}$ and Alternaria sp., ${ }^{20}$ but not for $V$. inaequalis. The AS-PCR developed here proved to be at least 10 times more sensitive than the CAPS method based on the difference in detection level in the test samples containing different ratios of the mutated allele. This was confirmed in the samples from the orchards: the G143A mutation was detected in mixed lesion samples that were first interpreted as free of the mutation by CAPS. Nevertheless, this latter method may provide additional information compared with the AS-PCR, i.e. the presence of both the wild-type and the mutant $C y t b$ allelebearing isolates occurring in a unique leaf sample. The digestion profiles indicate that in most cases $(98 \%)$ the samples contain both the wild-type and the mutant $C y t b$ alleles. This situation may result from the coexistence in the samples of leaf lesions colonised by either mutant or wild-type sensitive strains. Alternatively, leaf lesions may have been colonised by heteroplasmic fungal strains containing in their mycelia a mixed population of mitochondria with or without the G143A mutation. Both hypotheses could be tested by analysing separately different lesions from the corresponding orchards as well as single spore isolates, as it cannot be ruled out that a single lesion could result from a coinfection by a Qol-sensitive and a resistant isolate. Heteroplasmy has been demonstrated for fungicide-resistant isolates originating from commercial orchards. ${ }^{15}$

As anticipated, the present results clearly show a strong association between the occurrence of the G143A mutation and the detection of $\mathrm{Qol}$ resistance by in vitro spore germination 


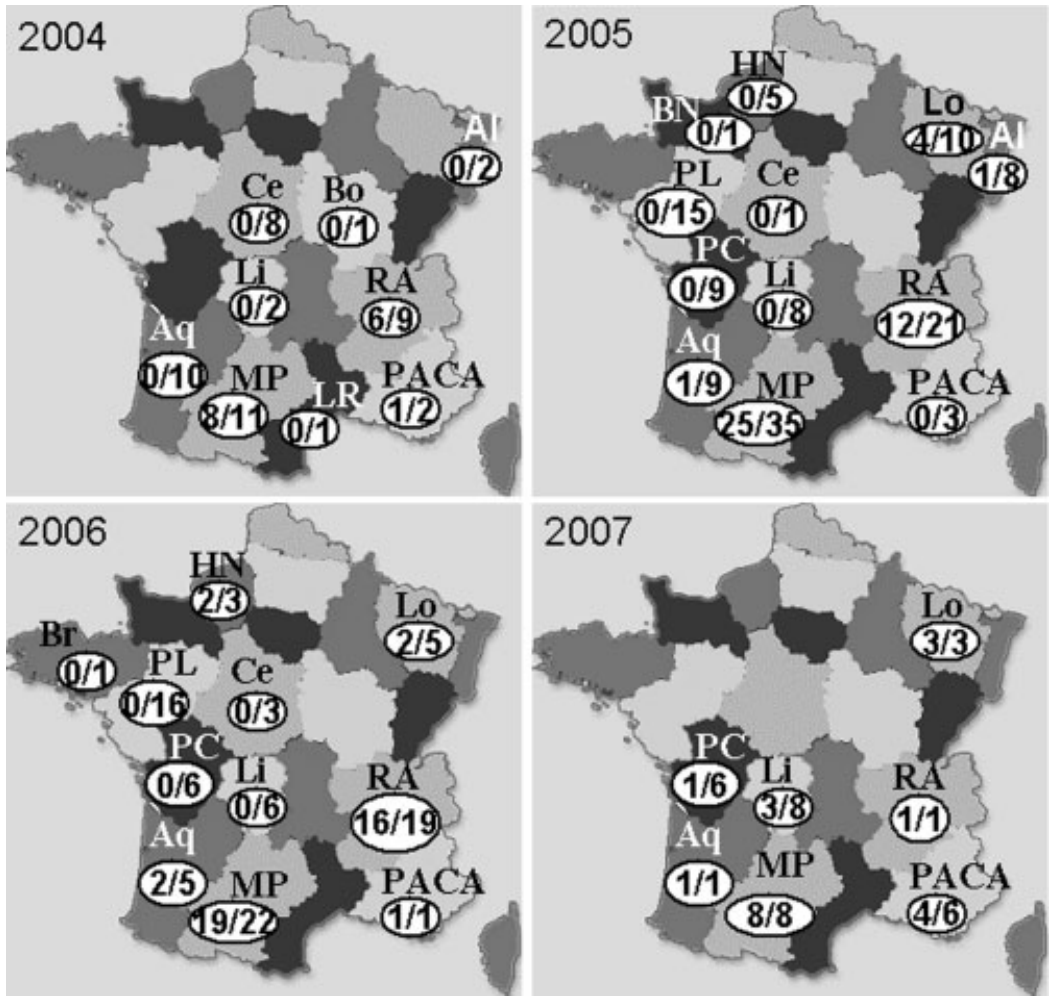

Figure 7. Distribution of the G143A mutation detected by PCR-based methods in French Venturia inaequalis populations sampled from 2004 to 2007. The number of populations where the point mutation was detected over the number of sampled orchards is indicated. The French administrative regions are as follows: Al, Alsace; Aq, Aquitaine; BN, Basse Normandie; Bo, Bourgogne; Br, Bretagne; Ce, Centre; HN, Haute Normandie; Li, Limousin; Lo, Lorraine; LR, Languedoc-Roussillon; MP, Midi-Pyrénées; PACA, Provence-Alpes-Côte d'Azur; PC, Poitou-Charentes; PL, Pays de Loire; RA, Rhône-Alpes.

assays. Furthermore, this mutation was also observed in many other samples that could not be studied by the in vitro assay. Altogether, these results demonstrate that the main cause of the failure to control apple scab using Qol fungicides arises from the spread of fungal strains harbouring this mutation. In a few cases, discrepancies between the spore germination assays and the molecular detection of the G143A mutation were observed. A high level of resistance in the absence of the G143A mutation could indicate that an alternative resistance mechanism is operating. Other resistance mechanisms have indeed been reported in $V$. inaequalis and/or in other fungi. Change from phenylalanine to leucine at position 129 of the Cyt $b$ polypeptide (mutation F129L) has been shown to occur in field populations of Pyricularia grisea Sacc. ${ }^{7,21}$ The present authors failed to detect this point mutation by sequencing the corresponding segment of the $V$. inaequalis gene amplified from one sample showing a moderate level of resistance without harbouring the G143A mutation (data not shown). The alternative oxidase pathway may also operate, thus leading to resistance, as previously demonstrated in $V$. inaequalis, ${ }^{10,14}$ although, in the present case, inclusion of SHAM in the spore germination medium did not modify strobilurin sensitivity (data not shown). Further experiments would be needed to identify the other mechanisms of Qol resistance in $V$. inaequalis.

In contrast, PCR-based detection of the G143A mutation in samples that were shown to be Qol-sensitive in spore germination assays is more difficult to interpret. It could be hypothesised that these samples were a mixture of lesions colonised by predominantly sensitive isolates versus Qol-resistant ones, and that only the former contributed, owing to germination bias, to the spore germination assay, whereas DNA from both lesions contributed to the molecular assay.

In addition to being more reliable than the spore germination assays, molecular monitoring is less time consuming. It was performed on 291 samples collected in the main apple-producing regions of France in orchards in which apple scab could not be controlled by the use of strobilurin. These orchards are, however, not representative of French orchards in terms of apple scab control. Multiple detection of Qol resistance in the French appleproducing regions raises the epidemiological question about its origin, i.e. frequent occurrence of independent G143A mutational events versus the long-distance dissemination of a single or of very few $\mathrm{G} 143 \mathrm{~A}$ alleles.

\section{SUPPORTING INFORMATION}

Supporting information may be found in the online version of this article.

\section{ACKNOWLEDGEMENT}

The authors are grateful to Pierre Leroux and Anne Sophie Walker from INRA of Versailles for their helpful advice during this work. They also thank all the technicians and growers for collecting and sending samples of leaves.

\section{REFERENCES}

1 Sauter H, Steglich W and Anke T, Strobilurins: evolution of a new class of active substances. Angew Chem Internat Ed 38:1328-1349 (1999). 
2 Bartlett DW, Clough JM, Godwin JR, Hall AA, Hamer M and ParrDobrzanski B, The strobilurin fungicides. Pest Manag Sci 58:649-662 (2002).

3 Sierotzki $\mathrm{H}$, Wullschleger J and Gisi U, Point mutation in cytochrome b gene conferring resistance to strobilurin fungicides in Erysiphe graminis f. sp. tritici field isolates. Pestic Biochem Physiol 68:107-112 (2000).

4 Sierotzki H, Parisi S, Steinfeld U, Tenzer I, Poirey S and Gisi U, Mode of resistance to respiration inhibitors at the cytochrome bc1 complex of Mycosphaerella fijiensis field isolates. Pest Manag Sci 56:833-841 (2000).

5 Ishii H, Fraaije BA, Sugiyama T, Noguchi K, Nishimura K, Takeda T, et al, Occurrence and molecular characterization of strobilurin resistance in cucumber powdery mildew and downy mildew. Phytopathology 91:1166-1171 (2001).

6 Chen WJ, Delmotte F, Richard-Cervera S, Douence L, Greif C and CorioCostet MF, At least two origins of fungicide resistance in grapevine downy mildew populations. Appl Environ Microbiol 73:5162-5172 (2007).

7 Grasso V, Palermo S, Sierotski H, Garibaldi A and Gisi U, Cytochrome b gene structure and consequences for resistance to Qo inhibitor fungicides in plant pathogens. Pest Manag Sci 62:465-472 (2006).

8 Küng Färber RB, Chin KM and Leadbitter N, Sensitivity of Venturia inaequalis to trifloxystrobin. Pest Manag Sci 58:261-267 (2002).

9 Jabs T, Cronshaw K and Freund A, New strobilurin resistance mechanism in apple scab (Venturia inaequalis). Phytomedizin 31:15-16 (2001).

10 Olaya G, Zheng D and Köller W, Differential responses of germinating Venturia inaequalis conidia to kresoxim-methyl. Pestic Sci 54:230-236 (1998).

11 Zheng D, Olaya Gand Köller W, Characterization of laboratory mutants of Venturia inaequalis resistant to the strobilurin-related fungicide kresoxim-methyl. Curr Genet 38:148-155 (2000).

12 Steinfeld U, Sierotski H, Parisi S, Poirey S and Gisi U, Sensitivity of mitochondrial respiration to different inhibitors in Venturia inaequalis. Pest Manag Sci 57:787-796 (2001).
13 Zheng D and Köller W, Characterization of the mitochondrial cytochrome $b$ gene from Venturia inaequalis. Curr Genet 32:361-366 (1997).

14 Jobin T and Carisse O, Incidence of myclobutanil- and kresoximmethyl-insensitive isolates of Venturia inaequalis in Quebec orchards. Plant Dis 91:1351-1358 (2007).

15 Dux H, Sierotzki H, Meier-Runge F and Gisi U, Sensitivity of Venturia inaequalis populations to anilinopyrimidine, DMI and Qol fungicides, in Modern Fungicides and Antifungal Compounds IV, ed. by Dehne H-W, Gisi U, Kuck K-H, Russell PE and Lyr H. British Crop Protection Council, Alton, UK, pp. 45-54 (2005).

16 Köller W, Parker DM, Turechek WW, Cruz AA and Cronshaw K, A twophase resistance response of Venturia inaequalis populations to the Qol fungicides kresoxim-methyl and trifloxystrobin. Plant Dis 88:537-544 (2004).

17 Sallato BV and Latorre BA, First report of practical resistance to Qol fungicides in Venturia inaequalis (apple scab) in Chile. Plant Dis 90:375 (2006).

18 Avila-Adame Cand Köller W, Characterization of spontaneous mutants of Magnaporthe grisea expressing stable resistance to the Qo-inhibiting fungicide azoxystrobin. Curr Genet 42:332-338 (2003).

19 Fraaije BA, Butters JA, Coelho JM, Jones DR and Hollomon DW, Following the dynamics of strobilurin resistance in Blumeria graminis f. sp. tritici using quantitative allele-specific real-time PCR measurements with the fluorescent dye SYBR Green I. Plant Pathol 51:45-54 (2002)

$20 \mathrm{MaZ}$ and Michailides TJ, An allele-specific PCR assay for detecting azoxystrobin-resistant Alternaria isolates from pistachio in California. J Phytopathol 152:118-121 (2004).

21 Kim YS, Dixon EW, Vincelli P and Farman ML, Field resistance to strobilurin (Qol) fungicides in Pyricularia grisea caused by mutations in the mitochondrial cytochrome b gene. Phytopathology 93:891-900 (2003) 